\title{
SOCIAL MEDIA PLATFORMS AND ONLINE PURCHASE: VIVID PERSPECTIVES AND THE EXTENT OF THEIR INFLUENCE
}

\author{
Dr. CHITRA RATHORE ${ }^{1} \&$ Dr. JITENDRA SINGH BIDAWAT ${ }^{2}$ \\ ${ }^{1}$ Associate Professor \& HOD BBA, S. S. Jain Subodh PG(Autonomous) College, Jaipur, Rajasthan, India \\ ${ }^{2}$ Associate Professor, Deptt. Of ABST, Mahaveer College of Commerce, Jaipur, Rajasthan, India
}

\begin{abstract}
ABSRACT
Web based life has reformed the methods of correspondence and sharing data and interests. The fast development of online networking and long range informal communication destinations, particularly, in creating nation like India is giving advertiser another road to contact clients. The examination endeavours to evaluate the effect of utilization of online life on buy choice procedure. The investigation finds that the online life is most broadly utilized in data hotspot for amusement, systems administration, and data on new brands. Likewise, the online life audits and feelings influence the buy choice procedure; be that as it may, propensity of offer their encounters post buy is shockingly acceptable. The research has been made on a sample size of 210residing in Jaipur to observe and study the buying preferences and features of online purchasers. earlier also the research has been done on this but in this research the researchers tried to bring forward the perceptions of online buying and the increasing role of social media in it.

KEYWORDS: Buying Behaviour, Market Players, Online, Purchase \& Social Media
\end{abstract}

Received: Jun 06, 2020; Accepted: Jun 26, 2020; Published: Aug 07, 2020; Paper Id.: IJMPERDJUN2020681

\section{INTRODUCTION}

The development of online business was driven by fast innovation selection drove by the expanding utilization of gadgets, for example, PDAs and tablets, and access to the web through broadband, $3 \mathrm{G}, 4 \mathrm{G}$, and so on expanded online purchaser base. Besides, supported socioeconomics and a developing web client base assisted with helping this development. As far as features, the development appeared by home-developed players, for example, Flipkart and Myntra and the gigantic financial specialist enthusiasm around these organizations showed the monstrous capability of the market. With the section of web based business behemoths, for example, Amazon and ebay, the opposition is relied upon to additionally increase. Both these global players accompany profound pockets and the tolerance to drive the Indian internet business.

The effect of web based life on online buy is high. It fills a fundamental need in internet promoting by helping organizations to build up more grounded web nearness, produce leads and increment traffic . An all around organized online networking procedure is significant for improving the turn of events and development of a web based business. Web based life keeps on picking up prominence attributable to its business accomplishment around the globe. A huge level of promoting efforts happen through online networking site. Remembering internet based life for a push to progress web based business can be profoundly helpful. It gives a powerful method to pull in light of a legitimate concern for the enormous crowds that utilizes web based life.

The utilization of online life has seen fast development over a period with a few people making buys through it. Numerous organizations have selected to make the most of the open doors introduced by web-based social 
networking systems to get more clients. Albeit some entrepreneurs might be incredulous about utilizing internet based life, actually it is a beneficial incorporation in web based advertising efforts.

- Social media destinations provide food for creative highlights, for example, 'similar to' catches and remark segments much of the time used to encourage discussions. Sharing data through online networking is significant in light of the effect it has on the decisions that individuals make while choosing items and administrations.

- -Incorporating Share catches for internet based life stages, for example, LinkedIn, Facebook and Twitter on your site will permit you to publicize your business and advance connection. A few internet based life clients make their buys online after they share things on Pinterest, Facebook and Twitter. This is an away from of how crucial web based life organizing is in web based business. Customers around the globe will go through billions of their well deserved cash every year through the available foundation of online networking.

\section{Value of Social Media}

Internet based life should be a piece of an organization's promoting spending plan since it gives an incredible method to make an association with the focused on crowd. From Instagram to LinkedIn, there are basically boundless approaches to cooperate and share data just as market the items. Interpersonal organizations empower to interface with new clients and keep in contact with the presence clients. Online networking improves client assistance by making availability to clients who tend to look for sure fire criticism. It reacts in an ideal way to their interests and requests. Purchasers depend on social locales to get some answers concerning items and administrations. Improved profiles and helpful data will make a positive initial introduction for online business.

\section{OBJECTIVES}

- To study the buyers profile that buy items from on the web;

- To distinguish the elements impact the clients to buy items through web based life;

- To discover the items bought through on the web; and

- To investigate the post buy conduct of shoppers.

\section{REVIEW OF LITERATURE}

Hoffman and Novak have shown that intuitiveness is the key distinctive component between promoting correspondence on the Internet and customary broad communications. Today online purchasers have more control and dealing power than customers of physical stores in light of the fact that the Internet offers more interactivities among shoppers and item/specialist organizations just as more noteworthy accessibility of data about items and administrations. Geissler and Zinkhan asserted that the Internet moved the perceived leverage for purchasers as it turned out to be simple for them to make shopping correlations and assess choices without being constrained by sales reps. Online stores diminish exchange costs and have advantage for the two customers and sellers. Armstrong, Armstrong et al.have the examination on purchaser purchasing conduct dependent on buy expectation has been created in showcasing for over 20 years. One issue stays debatable is whether buy expectation can successfully foresee buyer purchasing conduct. Norazah Suki and Norbayah Suki recommended advertisers ought to propose more on appealing advancement, for example, promotions or limits through the web. Yulihasri et al. considered the handiness of web shopping, convenience, similarity, protection, security, regulating convictions, self- 
adequacy, demeanor and understudy's purchasing goal. They found that web publicizing well impacts the buying of an organization's items. Customers progressively need what's known as a "consistent omnichannel understanding", which means one in which retailers permit them to join on the web and physical perusing, shopping, requesting and returning in whatever combo they might want. Sharma et al, evaluated the web based purchasing conduct of buyers in India, and found that customers are dreaded of unbound exchanges in online installment and greater part of online purchasers are from 18-25 years. Ioanas and Stoica address the effect of web based life on shopper conduct, purchasers favors internet purchasing for accommodation and a large portion of the clients are checking the item data before purchasing the items. Bauboniene and Guleviciute the primary components affecting shoppers to shop online are comfort, straightforwardness and better cost. Muda et al. explored that online buy conduct of Gen Y in Malaysia and recognize the variables drive the conduct. They found that Gen Y in Malaysia purchases generally from online retailers working through Facebook and Instagram.

\section{RESEARCH METHODOLOGY}

The examination configuration chose for the investigation is exploratory and expressive in nature. Exploratory examination configuration is characterized as "Examination concerning an issue or circumstance which gives experiences to the specialist. The exploration is intended to give subtleties where a modest quantity of data exists. It might utilize an assortment of techniques, for example, preliminary investigations, interviews, bunch conversations, tests, or different strategies to pick up data, and Descriptive examination incorporates overviews and actuality discovering enquiries of various types. The significant reason for graphic exploration is depiction of the situation as it exists at present.

The survey had the accompanying measurements:

- $\quad$ Socio and Economic profile of the respondent, for example, sexual orientation and age, training, occupation and pay

- The mechanical, shoppers and item/administration factors affecting the online buy.

- Behavior of visiting web based life destinations, recurrence of visits, sum spent and item bought.

- Various traits instigate online life clients are amusement, organizing, data on new brands, etc.

\section{Data Collection}

Information is gathered through essential sources. An all around organized poll arranged to gather information from respondents related Socio and Economic and traits instigate internet based life clients. Information was gathered from 210 respondents residing in Jaipur.

\section{Primary Data}

The essential information are those which are gathered a new and just because and in this manner happen to be unique in character. The essential information gathered through review. This investigation has gathered essential information through poll from different respondents, for example, understudies, teachers, private division workers and IT representatives.

\section{Secondary Data}

Optional information is the information that have been now gathered and promptly accessible from different sources, for example, different distributions of Central, State and Local Governments, different distributions of outside governments or International bodies, Technical and exchange diaries, Books, magazines, and new paper, reports arranged by research 
researchers, college financial analysts, etc.

Instruments for Analysis:

- $\quad$ Percentage Analysis;

- Cross Tabulation;

- $\quad$ Chi Square Test and

- $\quad$ Mean Score were utilized to dissect the gathered information.

\section{Percentage Analysis}

Table 1: Socio Economic Profile of Customers

\begin{tabular}{|c|c|c|c|}
\hline \multicolumn{2}{|c|}{ Particulars } & No. of Respondents & Percentage \\
\hline \multirow{4}{*}{ Age } & $18-25$ & 96 & 46.2 \\
\hline & $26-35$ & 72 & 33.5 \\
\hline & $>36$ & 42 & 20.3 \\
\hline & Total & 210 & 100 \\
\hline \multirow{3}{*}{ Gender } & Male & 126 & 60 \\
\hline & Female & 84 & 40 \\
\hline & Total & 210 & 100 \\
\hline \multirow{6}{*}{ Income } & $<10,000$ & 84 & 40 \\
\hline & $10,000-30,000$ & 42 & 20 \\
\hline & $30,000-50,000$ & 18 & 8.57 \\
\hline & $50,000-70,000$ & 24 & 11.43 \\
\hline & $>70,000$ & 42 & 20 \\
\hline & Total & 210 & 100 \\
\hline
\end{tabular}

Age

Out of 210 Respondents, $46.2 \%$ of the respondents are in the age group of 18-25, followed by $26--35$ (33.5\%), and more than 36(20.3\%). The minimum age of the respondents was 18 years and the maximum was 32 years, which shows that the respondents of various age groups are involved in online shopping. All of them had Social Media Account.

\section{Gender}

Outof210 (126)Respondents $60.0 \%$ of the respondents are male and (84) $40.0 \%$ are female who are all buying the products through online shopping.

\section{Income}

Out of 210 respondents, $40 \%$ are earning less than 10,000 Rs. per month, 20\% are earning Rs. 10,000-30,000 per month, 8.5\% are earning Rs. 30,000 -50000 per month, $11.43 \%$ are earning Rs. 50,000-70,000 per month and 20\% are earning more than 70,000 per month.

Table 2: Number of Respondents Based on Frequency of Accessing Social Media Account 


\begin{tabular}{|c|c|c|}
\hline Frequency of Accessing & Number of Respondents & Percentage \\
\hline Every Hour & 49 & 23.33 \\
\hline Every Day & 63 & 30 \\
\hline Every Week & 35 & 16.67 \\
\hline Fortnightly & 38 & 18.1 \\
\hline Once in a Month & 25 & 11.9 \\
\hline Total & 210 & 100 \\
\hline
\end{tabular}

The table. 2 presents the frequency of accessing social media a/c by respondents. Accessing frequency measurement ranges from one hour to once in month. $23.33 \%$ of respondents are accessing their social media accounts every hour followed by $30 \%$ were accessing every day. $16.67 \%$ access every week rest $18.1 \%$ access fortnightly and $11.9 \%$ once in a month respectively.

Table 3: Number of Respondents Based on Time Spent on Social Media

\begin{tabular}{|c|c|c|}
\hline Time Spent(in Hours) & No. of Respondents & Percentage \\
\hline$<1$ & 28 & 13.33 \\
\hline 1 to 5 & 126 & 60 \\
\hline 5 to 8 & 42 & 20 \\
\hline$>8$ & 14 & 6.67 \\
\hline Total & $\mathbf{2 1 0}$ & $\mathbf{1 0 0}$ \\
\hline Source: Primary Data & \\
\hline
\end{tabular}

The table. 3 represents the time spent on social media by respondents in a day. Times spent are ranges from $1 \mathrm{hr}$ to more than to 8 hours.60\% of respondents spends 1 to 5 hours a day with social media, followed by $20 \%$ is $5-8$ hours and rest $6.67 \%$ spent more than 8 hours. The table proves that most of the respondents (120) spent 1-5 hours on social media for vivid purposes.

Table 4: Number of Respondents Based on the Number of Bands following in Social Medial

\begin{tabular}{|c|c|c|}
\hline Number of Brands & Number of Respondents & Percentage \\
\hline 1 & 51 & 24.3 \\
\hline 2 & 54 & 25.7 \\
\hline 3 & 15 & 7.1 \\
\hline$>3$ & 90 & 42.9 \\
\hline Total & $\mathbf{2 1 0}$ & $\mathbf{1 0 0}$ \\
\hline Source: Primary Data & \multicolumn{2}{|}{} \\
\hline
\end{tabular}

The table 4 displays the number of brands followed by respondents in social media. Their numbers are ranging from1to $>3$. Most of the respondents (42.9\%) are following more than 3 brands in social media, $25.7 \%$ of respondents are following two brands, $24.3 \%$ are only one and $7.1 \%$ are following 3 brands on social media. 
Table 5: Number of Respondents Based on the Products Generally Purchased through Online

\begin{tabular}{|c|c|c|}
\hline Products Purchased & $\begin{array}{l}\text { Number of } \\
\text { Respondents }\end{array}$ & Percentage \\
\hline Books \& Stationary & 7 & 3.33 \\
\hline Electronics \& Accessories & 42 & 20 \\
\hline Clothes, PC \& Mobile & 42 & 20 \\
\hline Cosmetics & 21 & 10 \\
\hline Kitchen Utensils & 14 & 6.67 \\
\hline Furniture & 7 & 3.33 \\
\hline Clothes, PC \& Mobile Accessories, Kitchen utensils & 35 & 16.67 \\
\hline Electronics Accessories Cloths, PC and Mobile & 28 & 13.33 \\
\hline Electronics, Cloths, PC, Mobile and Kitchen Utensils & 14 & 6.67 \\
\hline Total & 210 & 100 \\
\hline
\end{tabular}

The table 5 shows the list of products usually purchased by the respondents online out of 210 respondents $20 \%$ of respondents bought only electronic items such as pc and mobile accessories. $20 \%$ purchased Electronics, Clothes PC and Mobile Accessories, 10\%bought cosmetics, 16.67 purchased Clothes, PC and Mobile accessories and kitchen accessories, $3.33 \%$ spent on different heads such as books, electronics, kitchen accessories, furniture each constitutes $3.33 \%$ respectively. Electronics, clothes, PC and Mobile accessories are purchased largely online.

Table 6: Number of Respondents Based on Mode of Payment

\begin{tabular}{|c|c|c|}
\hline Mode of Payment & Number of Respondents & Percentage \\
\hline Cash on Delivery & 90 & 42.86 \\
\hline Wallet & 63 & 30 \\
\hline Credit/Debit Card & 42 & 20 \\
\hline Net Banking & 15 & 7.14 \\
\hline Total & 210 & 100 \\
\hline
\end{tabular}

The table 6 depicts distribution of respondents on the basis of Mode of Payment. every respondent(100\%)purchased variety of products online. Of those $42.86 \%$ of respondents preferred COD, $20 \%$ preferred credit/debit card payment and rest $7.14 \%$ chose net banking as mode of payment for online purchase.

Table 7: Number of Respondents Based on Amount Spent on Buying Through Online

\begin{tabular}{|c|c|c|}
\hline Amount Spent ( in Rs.) & Number of Respondents & Percentage \\
\hline$<1000$ & 63 & 30 \\
\hline $1000-5000$ & 35 & 16.67 \\
\hline $5000-10,000$ & 42 & 20 \\
\hline $10,000-15,000$ & 35 & 16.67 \\
\hline $15,000-20,000$ & 21 & 10 \\
\hline$>20,000$ & 14 & 6.66 \\
\hline Total & 210 & 100 \\
\hline
\end{tabular}

The table.7 shows the distribution of respondents according to the amount spent in the last 2 months through online. $30 \%$ spent less than Rs.1000 on online, $16.67 \%$ spent Rs. $1000-5000$ on online, $20 \%$ spent Rs. $5000-10000$ on online, $16.67 \%$ spent Rs. $10000-15000$ on online, $10 \%$ spent Rs. 15000-20000 on online, $6.66 \%$ spent more than Rs 20000.

\section{Hypothesis Testing}

- $\quad$ significant association between age and buying behaviour

\section{Hypothesis}


- $\mathrm{H}_{0}$ : There is no significant association between age and buying behaviour.

- $\mathrm{H}_{1}$ : There is significant association between age and buying behaviour.

\section{Result of Data Analysis}

Table 8

\begin{tabular}{|c|c|c|c|c|c|}
\hline \multirow{2}{*}{$\begin{array}{c}\text { Number of Products } \\
\text { Purchased }\end{array}$} & \multicolumn{3}{|c|}{ Age } & \multirow{2}{*}{ Row Totals } & \multirow[b]{2}{*}{ D F $=6$} \\
\hline & $18-25$ & $26-35$ & 36 \& Above & & \\
\hline 1 & $\begin{array}{c}60(61.11) \\
{[0.02]}\end{array}$ & $\begin{array}{c}12(14.17) \\
{[0.33]} \\
\end{array}$ & $\begin{array}{c}21(17.71) \\
{[0.61]} \\
\end{array}$ & 93 & Table value $=12.592$ \\
\hline 2 & $\begin{array}{c}27(25.63) \\
{[0.07]}\end{array}$ & $\begin{array}{c}6(5.94) \\
{[0.00]}\end{array}$ & $\begin{array}{c}6(7.43) \\
{[0.27]} \\
\end{array}$ & 39 & \\
\hline 3 & $\begin{array}{c}12(9.86) \\
{[0.47]}\end{array}$ & $\begin{array}{c}2(2.29) \\
{[0.04]}\end{array}$ & $\begin{array}{c}1(2.86) \\
{[1.21]}\end{array}$ & 15 & $\begin{array}{l}\text { The chi-square statistic } \\
\text { is } 3.759\end{array}$ \\
\hline$>3$ & $\begin{array}{c}39(41.40) \\
{[0.14]}\end{array}$ & $\begin{array}{c}12(9.60) \\
{[0.60]}\end{array}$ & $\begin{array}{c}12(12.00) \\
{[0.00]}\end{array}$ & 63 & \\
\hline Column Totals & 138 & 32 & 40 & $\begin{array}{l}210 \text { (Grand } \\
\text { Total) }\end{array}$ & \\
\hline
\end{tabular}

- $\quad \mathrm{DF}=6$, Table Value at $5 \%$ level of Significance $=12.592$

Interpretation: A chi-square test of independence showed that there was no significant association between age and buying behavior as the chi-square statistic 3.759 is less than table value 12.592 at $5 \%$ level of significance.

- $\quad$ significant Association between Gender and Buying Behaviour:

Hypothesis

- $\quad H_{0}$ : There is no significant Association between Gender and Buying Behaviour.

- $\quad H_{1}$ : There is significant Association between Gender and Buying Behaviour.

\section{Result of Data Analysis}

\begin{tabular}{|c|c|c|c|c|}
\hline \multicolumn{5}{|c|}{ Table 9} \\
\hline \multirow{2}{*}{$\begin{array}{c}\text { Number of Products } \\
\text { Purchased }\end{array}$} & \multicolumn{2}{|c|}{ Gender } & \multirow{2}{*}{ Row Totals } & \\
\hline & Male & Female & & $\mathrm{DF}=3$ \\
\hline 1 & $\begin{array}{c}63(54.47) \\
{[1.34]}\end{array}$ & $\begin{array}{c}30(38.53) \\
{[1.89]}\end{array}$ & 93 & Table Value $=7.815$ \\
\hline 2 & $\begin{array}{c}16(21.67) \\
{[1.48]}\end{array}$ & $\begin{array}{c}21(15.33) \\
{[2.10]}\end{array}$ & 37 & $\begin{array}{l}\text { chi-square statistic is } \\
23.3444\end{array}$ \\
\hline 3 & $\begin{array}{c}11(21.09) \\
{[4.82]}\end{array}$ & $\begin{array}{c}25(14.91) \\
{[6.82]}\end{array}$ & 36 & \\
\hline$>3$ & $\begin{array}{c}33(25.77) \\
{[2.03]}\end{array}$ & $\begin{array}{c}11(18.23) \\
{[2.87]}\end{array}$ & 44 & \\
\hline Column Totals & 123 & 87 & $\begin{array}{l}210 \text { (Grand } \\
\text { Total) }\end{array}$ & \\
\hline
\end{tabular}

- Interpretation: A chi-square test of independence showed that there was a significant association between Gender and buying behavior as the chi-square statistic 23.3444 is more than table value 7.815 at $5 \%$ level of significance.

- Significant Association between Income and Buying Behaviour:

Hypothesis 
- $\quad H_{0}$ : There is no Significant Association between Income and Buying Behaviour.

- $\quad H_{1}$ : There is Significant Association between Income and Buying Behaviour.

Result of Data Analysis

Table 10

\begin{tabular}{|c|c|c|c|c|c|c|}
\hline \multirow{2}{*}{$\begin{array}{c}\text { Number of Products } \\
\text { Purchased }\end{array}$} & \multicolumn{5}{|c|}{ Income } & \multirow[t]{2}{*}{ Row Totals } \\
\hline & $<10,000$ & $\begin{array}{l}10,000- \\
30,000\end{array}$ & $\begin{array}{l}30,000- \\
50,000\end{array}$ & $\begin{array}{l}50,000- \\
70,000\end{array}$ & $>70,000$ & \\
\hline 1 & $\begin{array}{c}27(25.24) \\
{[0.12]}\end{array}$ & $\begin{array}{c}18(14.61) \\
{[0.78]}\end{array}$ & $\begin{array}{c}9(13.29) \\
{[1.38]}\end{array}$ & $\begin{array}{c}18(22.59) \\
{[0.93]}\end{array}$ & $\begin{array}{c}21(17.27) \\
{[0.80]}\end{array}$ & 93 \\
\hline 2 & $\begin{array}{c}12(10.59) \\
{[0.19]}\end{array}$ & $\begin{array}{c}3(6.13) \\
{[1.60]}\end{array}$ & $\begin{array}{c}9(5.57) \\
{[2.11]} \\
\end{array}$ & $\begin{array}{c}12(9.47) \\
{[0.68]} \\
\end{array}$ & $\begin{array}{c}3(7.24) \\
{[2.49]}\end{array}$ & 39 \\
\hline 3 & $\begin{array}{c}3(4.07) \\
{[0.28]}\end{array}$ & $\begin{array}{c}3(2.36) \\
{[0.18]}\end{array}$ & $\begin{array}{c}3(2.14) \\
{[0.34]}\end{array}$ & $\begin{array}{c}3(3.64) \\
{[0.11]}\end{array}$ & $\begin{array}{c}3(2.79) \\
{[0.02]}\end{array}$ & 15 \\
\hline$>3$ & $\begin{array}{c}15(17.10) \\
{[0.26]}\end{array}$ & $\begin{array}{c}9(9.90) \\
{[0.08]}\end{array}$ & $\begin{array}{c}9(9.00) \\
{[0.00]}\end{array}$ & $\begin{array}{c}18(15.30) \\
{[0.48]}\end{array}$ & $\begin{array}{c}12(11.70) \\
{[0.01]}\end{array}$ & 63 \\
\hline Column Totals & 57 & 33 & 30 & 51 & 39 & $\begin{array}{c}210 \text { (Grand } \\
\text { Total) }\end{array}$ \\
\hline
\end{tabular}

- Interpretation: A chi-square test of independence showed that there was no significant association between age and buying behaviour as the chi-square statistic 12.8356 is less than table value 21.026 at $5 \%$ level of significance.

\section{FINDINGS AND CONCLUSIONS}

It was found that the most of the males were active in online purchases and the people of age group 18-25 are more prompt in online purchases. 1-5 hours a day are spent by most (60\%) of the people. Frequently purchased articles online are electronic items, cloths, Pcs and mobiles. 42.86\% prefer COD while doing online purchasing. 16.67\% people spent 1000-5000 and 10000-15000 Rs. In last two months on online purchasing.

Interpersonal organizations have a job in affecting the conduct of shoppers in the virtual conditions, especially when the level of presentation of messages and the connection made between the assortment of data given and the client who is going to make a buy. There are numerous individuals who are as purchasers of specific items, for example, gadgets, garments, books, home apparatuses are bought through on the web. While going to the most significant trait that causes a buyer to decide to purchase items through online are quality, security of credit/platinum cards, and assortment of items, etc. According to the exploration shoppers ordinarily go through over three hours per day on the web based life and the significant reason for existing was discovered to be long range interpersonal communication and data gathering. Customers depend upon more than one medium so as to improve their image related information. It implies that they utilize the mix of different hotspots for settling on definite buy choice. Alongside the conventional sources, they intensely depend on current showcasing instrument for example internet publicizing. Shoppers do require point by point data about the brand in order to assess its qualities and shortcomings; this abundant measure of data spares their time by permitting them to settle on the buy choice rapidly.

\section{REFERENCES}

1. NorazahMohd Suki and NorbayahMohd Suki, (2016) Examination of Mobile Social Networking Service (SNS) Users' Loyalty: A Structural Approach", International Journal of Social Ecology and Sustainable Development, Vol. 7, No. 3, pp. 57-70, 2016. 
2. Renuka Sharma, Kiran Metha and Shashank Sharma, "Understanding Online Shopping Behaviour of Indian Shoppers", International Journal of Management and Business Studies, Vol. 4, No. 3, pp. 9-18,2014.

3. Yulihasri, Md. Aminul Islam and Ku Amir Ku Daud, "Factors that Influence Customers' buying Intention on Shopping Online", International Journal of Marketing Studies, Vol. 3, No. 1, pp. 128-139,2011.

4. Rathore, Chitra," Article Review on E-Marketing”, Research Journal of Arts, Management and Social Sciences, Vol.- XV, Eng-II, Year-VIII, pp.85-91, Sept., 2016.

5. J. Scott Armstrong, Vicki G. Morwitzb and V. Kumar, "Sales Forecasts for Existing Consumer Products and Services: Do Purchase Intentions Contribute to Accuracy?”, International Journal of Forecasting, Vol. 16, No. 3, pp. 383-397,2000.

6. Jonathan M. Lace (2004), "At the crossroads of marketing communications and the Internet: experiences of UK advertisers", Internet Research, Vol. 14, No. 3, pp. 236-244.

7. ElisabetaIoanas and Ivona Stoica, “Social Media and Its Impact on Consumers Behavior”, International Journal of Economic Practices and Theories, Vol. 4, No. 2, pp. 295-303, 2014.

8. D. Hoffman and T. Novak, "Marketing in Hypermedia Computer-Mediated Environments: Conceptual Foundations", Journal of Marketing, Vol. 60, No. 3, pp. 50- 68, 1996.

9. Hasan, Haslinda, Amran Harun, and MohdShaffran Zainal Rashid. "Factors influencing online purchase intention in online brand." International Journal of Business Management \& Research 5.5 (2015): 63-72.

10. Gary L. Geissler and George M. Zinkhan, "Consumer Perceptions of the World Wide Web: an Exploratory Study using Focus Group Interviews", Advances in Consumer Research, Vol. 25, pp. 386-392, 1998.

11. Social Media Marketing India Trends Study, Available at: http://www.ey.com/in/en/services/advisory/ey-social- mediamarketing-india-trends-study-2016.

12. Social Media in India, Available at: http://www.livemint.com/Politics/FqcL24fK5aQ68qC6KzohJO/Social-media-in-India.html.

13. Rajeswari, M. "A study on the customer satisfaction towards online shopping in Chennai City." International Journal of Sales \& Marketing Management Research and Development 5.1 (2015): 1-10.

14. GlobalSocialMediaResearchSummary2017, Availableat: http://www.smartinsights.com/social-media-marketing/social-mediastrategy/new-global-social-media- research/.

15. E-commerce and Online Shopping in India-Statistics and Facts, Available at: https://www.statista.com/topics/2454/ecommerce-in-indial.

16. Punekar, Sarika, and R. Gopal. "A Study to Identify Customer's Online Apparel Shopping Behavior in Relation to Return Policies of E-Commerce Businesses, WR To Pune Region, India." International Journal of Sales \& Marketing, Management Research and Development (IJSMMRD) 6.3 (2016): 1-6.

17. The Latest Numbers on Web, Mobile, and Social Media in India (Infographic), Availableat: https://www.techinasia.com/indiaweb-mobile-data-series- 2016.

18. The Wall Street, Available at: http://online.wsj.com/ news/articles/SB10001424127887324063304578523112193480212, Accessed on 2012.

19. Andreas M. Kaplan and Michael Heinlein, "Collaborative Projects (Social Media Application): About Wikipedia, the Free Encyclopedia”, Business Horizons, Vol. 57, No. 5, pp. 617-626, 2014. 
20. MazziniMuda, Rohani Mohdand Salwana Hassan, "Online Purchase Behavior of Generation Y in Malaysia”, Procedia Economics and Finance, Vol. 37, pp. 292-298,2016.

21. Agrawal, Kalpana, and HuzefaJaliwala. "Effect of social media on e-purchase amongst youth." International Journal of Business Management \& Research 3.2 (2013): 131-136.

22. Versha Mehta and Vinod Kumar, “Online Buying Behavior of Customers: A Case Study of Northern India”, Pranjana, Vol. 15, No. 1, pp. 71-88, 2012.

23. Baer, W. S. (1998). Will the Internet Bring Electronic Services to the Home? Business Strategy Review, 9(1 (Spring)), 29-36.

24. Zettelmeyer, F. (2000). Expanding to the Internet: Pricing and Communications Strategies When Firms Compete on Multiple Channels. Journal of Marketing Research, ((August)), 292-308.

25. Zivile Bauboniene and Gintare Guleviciute, "E-Commerce Factors Influencing Consumers Online Shopping Decision”, Social Technologies, Vol. 5, No. 1, pp. 74-81, 2015. 